\title{
Diapause and post-diapause quiescence demonstrated in overwintering Harmonia axyridis (Coleoptera: Coccinellidae) in northwestern Europe
}

\author{
C. Lidwien RAAK-VAN DEN BERG ${ }^{1}$, Peter W. DE JONG ${ }^{1}$, Lia HEMERIK ${ }^{2}$ and Joop C. VAN LENTEREN ${ }^{1}$ \\ ${ }^{1}$ Laboratory of Entomology, Wageningen University, P.O. Box 8031, 6700 EH, Wageningen, The Netherlands; \\ e-mails: LidwienRaakvandenBerg@gmail.com; Peter.deJong@wur.nl; Joop.vanLenteren@wur.nl \\ ${ }^{2}$ Biometris, Wageningen University, Wageningen, The Netherlands; e-mail: lia.hemerik@wur.nl
}

Key words. Coleoptera, Coccinellidae, Harmonia axyridis, invasive species, hibernation, diapause, quiescence, pre-oviposition period, semi-field experiment

\begin{abstract}
The Asian ladybird Harmonia axyridis (Pallas) (Coleoptera: Coccinellidae) is regarded as an invasive species in many parts of the world. In a previous study we hypothesised that $H$. axyridis enters diapause at the end of October and then shifts to a quiescent state in December in northwestern Europe. In the present study we test this idea of a short, early period of diapause by sampling beetles from their hibernation sites immediately after their migratory flights in October, subsequently keeping them in outdoor cages, and then, after certain time-intervals, measuring the pre-oviposition time under optimal egg-laying laboratory conditions at $25^{\circ} \mathrm{C}$. We did this at both short $(12 \mathrm{~L})$ and long $(16 \mathrm{~L})$ photoperiods, since a photoperiodic response is an indicator of true diapause, rather than quiescence. A significant, albeit small, difference in pre-oviposition period between the two photoperiods, which disappears in December, corroborates our earlier hypothesis that the ladybirds are in a state of diapause until mid-December. Compared with that of native ladybirds the diapause of $H$. axyridis generally is relatively short and weak; moreover, it appears to have become shorter over the last decade. This flexibility in diapausing behaviour may be an important factor that contributes to the invasive success of $H$. axyridis.
\end{abstract}

\section{INTRODUCTION}

Dormancy is a state in which metabolism is greatly slowed down and development and reproduction are suppressed (Tauber et al., 1986; Denlinger, 2002). In this state, an organism is able to survive a period of unfavourable conditions, such as a prolonged period of low temperatures, and the development of active life stages is synchronised with favourable conditions (Hodek, 2012b). Dormancy can occur in any season; in winter it is also called hibernation (Tauber et al., 1986). Overwintering dormancy has been shown to be diapause initiated and diapause maintained in most insects [including all ladybirds studied (Hodek, 2012a, b)].

Diapause is induced by environmental cues, long before the onset of adverse conditions. During diapause, modifications in physiology (e.g. arrestment of growth and ovariole development), morphology (increased fat body), and behaviour (search for protected sites) occur. This socalled diapause syndrome is species-specific (Tauber et al., 1986; Denlinger, 2002). Even when conditions temporarily improve, diapause will persist.

Over time, sensitivity to the diapause-maintaining stimuli usually decreases, which results in a gradual termination of diapause (Tauber et al., 1986; Denlinger, 2002). In contrast, quiescent insects are in a reversible state of very low activity and suppressed metabolism: they remain highly responsive to changing environmental conditions and when favourable conditions return they can immediately resume development or reproduction (Tauber et al., 1986).
When unfavourable conditions are encountered after diapause termination, most insects remain dormant and enter a state of post-diapause quiescence. In this case, the characteristic diapause symptoms remain, but the insects are in a quiescent state and can react immediately when favourable environmental conditions develop (Tauber et al., 1986; Hodek, 2012b).

The developmental stage in which insects enter diapause is species-dependent (Tauber et al., 1986); in Harmonia axyridis (Pallas) (Coleoptera: Coccinellidae) it is the adult stage. Diapause of the adult stages is also known as reproductive diapause as the most conspicuous aspect is the cessation or suspension of reproduction in mature insects (Hodek, 2012a).

The multicoloured Asian ladybird $H$. axyridis is an efficient predator of aphids. It was first introduced as biological control agent in Europe in 1982, has established in the late 1990s and has rapidly spread since 2002 (Brown et al., 2011). Harmonia axyridis is now regarded as an invasive species because it has a negative effect on nontarget insect species, fruit production, and human health (Brown et al., 2008; Koch \& Galvan, 2008; Van Lenteren et al., 2008; De Clercq \& Bale, 2011). In addition, the establishment of $H$. axyridis is associated with a decline in native ladybird populations (Michaud, 2002; Alyokhin \& Sewell, 2004; Brakefield \& de Jong, 2011; Roy et al., 2012). As a result of these harmful effects, the ladybird is no longer commercially available in most of Europe (Van Lenteren, 2012).

Differences in life history characteristics between alien $H$. axyridis and native species of the same guild, deter- 


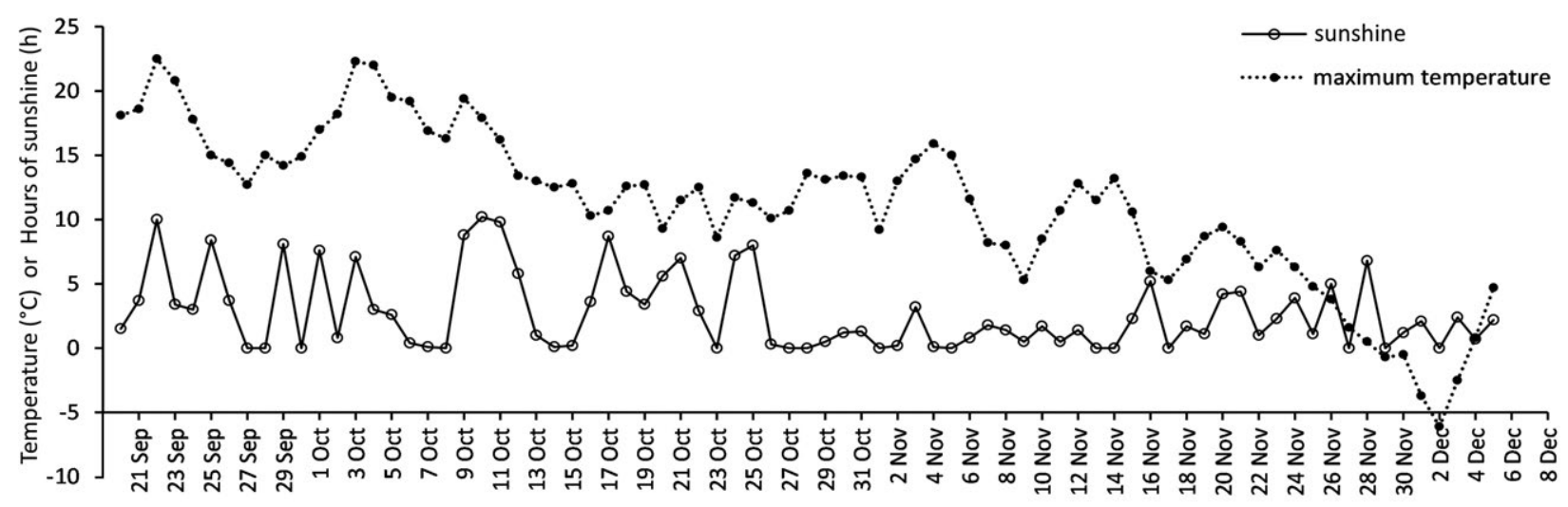

Date 2010

Fig. 1. Maximum daily temperature and total daily number of hours of sunshine in autumn 2010 in the Netherlands (KNMI, 2011).

mine, among other factors, the invasive success of the alien species. Winter survival of $H$. axyridis is high, and therefore results in large spring populations, which contribute to a rapid population build-up (Raak-van den Berg et al., 2012b). Depending on the climate, overwintering of $H$. axyridis in the Northern Hemisphere takes place between October and April and lasts three to six months (Tanagishi, 1976). The mode of overwintering of $H$. axyridis has been studied at several locations in Japan and Europe (Sakurai et al., 1992; Ongagna \& Iperti, 1994; Iperti \& Bèrtand, 2001; Berkvens et al., 2008; Reznik \& Vaghina, 2011). These studies demonstrate that $H$. axyridis has the typical aspects of the diapause syndrome: ovaries of hibernating females are underdeveloped, the corpora allata are atrophied, and the fat body is developed (Sakurai et al., 1992; Iperti \& Bèrtand, 2001). Moreover, the beetles show characteristic migration and overwintering-site-selection behaviour long before true winter conditions set in (Obata, 1986; Nalepa et al., 2005; Raak-van den Berg et al., 2012a). In laboratory studies Berkvens et al. (2008) and Ongagna \& Iperti (1994) were able to induce reproductive diapause in $H$. axyridis under short day conditions; characterised by a prolonged preoviposition period, empty gut, regressed ovaries, developed fat body, minimal food uptake, low activity, and aggregation behaviour.

A further indication of diapause rather than quiescence is the presence of a photoperiodic response. In temperate climates, the diapause-inducing and maintaining stimulus for insects is often a short photoperiod (Hodek et al., 1977; Hodek \& Ruzicka, 1979; Obrycki et al., 1983; Tauber et al., 1986). The photoperiodic response can be quantified as the difference in duration of the preoviposition period under short- and long-day photoperiods. A loss of photoperiodic response indicates the end of diapause and, depending on the moment during overwintering that this occurs, the insects may enter an environmentally-maintained period of post-diapause quiescence (Hodek \& Ruzicka, 1979; Tauber et al., 1986; Hodek \& Hodkova, 1988; Denlinger, 2002).

We hypothesized earlier that in northwestern Europe $H$. axyridis enters diapause at the end of October and then shifts to a post-diapause quiescent state in December
(Raak-van den Berg et al., 2012a). In this earlier study, we started our observations of the length of the preoviposition period of $H$. axyridis only from December onwards, and using only one light regime. Thus, we were not able to determine the pre-oviposition period, nor the ladybird's response to photoperiod, during the month of supposed diapause, which is assumed to start after the migratory flights in October. In this paper we test the hypothesis that $H$. axyridis enters a short period of diapause, followed by a period of quiescence, by monitoring pre-oviposition periods of beetles that were sampled immediately after the first migratory flights occurred. As an indicator of diapause, the presence of a photoperiodic response was determined by measuring the pre-oviposition period at both short and long photoperiods.

\section{MATERIAL AND METHODS}

\section{Sampling of Harmonia axyridis}

Due to the very low numbers of $H$. axyridis found in comparison to previous years (Raak-van den Berg et al., 2012a), it was not possible to restrict the sampling to one location and one date. Several sites used for hibernation by $H$. axyridis in previous years were monitored from September onwards, and the first aggregations of $H$. axyridis were sampled on 8 October 2010, one day after the first flight. After that, samples were taken on various dates and at various locations of which the precise date of migratory flights is not always known (Table 1). From mid-October onwards, the maximum daily temperature was around $12{ }^{\circ} \mathrm{C}$ and from the end of October onwards the daily number of hours of sunshine was about one hour (Fig. 1) (KNMI, 2011). This suggests that by the end of October no more migratory flights could have taken place, as other studies report that temperatures of about $18^{\circ} \mathrm{C}$ are needed to support migratory flights (Obata, 1986; Nalepa et al., 2005). The majority of the aggregations had been sampled by early November, shortly after the migratory flights.

Distances in the Netherlands are small and all locations are relatively close to one another: within a circle with a $75-\mathrm{km}$ radius. Besides, the characteristics of the hibernation quarters (Raak-van den Berg et al., 2012b) probably influence hibernation more than the location. To track any influence of locations, beetles from two locations were used for each time point (Tilburg and another location), from the moment onward that the large Tilburg population was collected. 
TABLE 1. Sampling locations, sampling dates, and sample sizes of aggregated hibernating Harmonia axyridis adults in winter 2010-2011, the Netherlands.

\begin{tabular}{|c|c|c|c|c|c|c|}
\hline \multirow[t]{2}{*}{ Location } & \multirow[t]{2}{*}{ Coordinates } & \multirow{2}{*}{$\begin{array}{l}\text { Aggregation } \\
\text { reported }\end{array}$} & \multirow{2}{*}{$\begin{array}{l}\text { Sampling } \\
\text { date }\end{array}$} & \multirow[t]{2}{*}{ Sampling site } & \multicolumn{2}{|c|}{$\begin{array}{l}\text { Number of } H \text {. } \\
\text { axyridis used }\end{array}$} \\
\hline & & & & & q & $\hat{0}$ \\
\hline Alkmaar & $\begin{array}{l}52^{\circ} 37^{\prime} 57^{\prime \prime} \mathrm{N} \\
4^{\circ} 44^{\prime} 35^{\prime \prime} \mathrm{E}\end{array}$ & End of October & $20 \mathrm{Nov}$ & $\begin{array}{l}\text { Inside, on stone wall of unheated } \\
\text { church tower }\end{array}$ & 40 & 60 \\
\hline Alphen a/d Rijn & $\begin{array}{l}52^{\circ} 7^{\prime} 27^{\prime \prime} \mathrm{N} \\
4^{\circ} 40^{\prime} 2^{\prime \prime} \mathrm{E}\end{array}$ & End of October & 26 Oct & Inside, unheated room & 76 & 56 \\
\hline Alphen a/d Rijn & $\begin{array}{l}52^{\circ} 8^{\prime} 33^{\prime \prime} \mathrm{N} \\
4^{\circ} 39^{\prime} 22^{\prime \prime} \mathrm{E}\end{array}$ & End of October & $\begin{array}{l}29 \text { Oct } \\
\text { and } 18 \mathrm{Nov}\end{array}$ & Outside, in steel window frames & 44 & 44 \\
\hline Deelen & $\begin{array}{l}52^{\circ} 3^{\prime} 53^{\prime \prime} \mathrm{N} \\
5^{\circ} 53^{\prime} 23^{\prime \prime} \mathrm{E}\end{array}$ & & $3 \mathrm{Nov}$ & Outside, between stone wall and shutters & 40 & 40 \\
\hline Deelen & $\begin{array}{l}52^{\circ} 3^{\prime} 37^{\prime \prime} \mathrm{N} \\
5^{\circ} 53^{\prime} 54^{\prime \prime} \mathrm{E}\end{array}$ & & $3 \mathrm{Nov}$ & Outside, between stone wall and shutters & 40 & 20 \\
\hline Doesburg & $\begin{array}{l}52^{\circ} 0^{\prime} 57^{\prime \prime} \mathrm{N} \\
6^{\circ} 8^{\prime} 9^{\prime \prime} \mathrm{E}\end{array}$ & End of October & $3 \mathrm{Nov}$ & Inside, unheated room & 68 & 88 \\
\hline Kootwijk & $\begin{array}{l}52^{\circ} 10^{\prime} 39^{\prime \prime} \mathrm{N} \\
5^{\circ} 45^{\prime} 39^{\prime \prime} \mathrm{E}\end{array}$ & $\begin{array}{l}7 \text { October } \\
\text { and } 14 \text { October }\end{array}$ & $\begin{array}{c}8 \text { Oct } \\
\text { and } 15 \text { Oct }\end{array}$ & $\begin{array}{l}\text { Outside, between stone wall and shutters } \\
\text { Inside, unheated and heated rooms }\end{array}$ & 108 & 108 \\
\hline Tilburg & $\begin{array}{l}51^{\circ} 33^{\prime} 22^{\prime \prime} \mathrm{N} \\
5^{\circ} 4^{\prime} 7^{\prime \prime} \mathrm{E}\end{array}$ & & $30 \mathrm{Nov}$ & $\begin{array}{l}\text { Inside, on stone wall of unheated } \\
\text { water tower }\end{array}$ & 227 & 227 \\
\hline Wageningen & $\begin{array}{l}51^{\circ} 58^{\prime} 53^{\prime \prime} \mathrm{N} \\
5^{\circ} 40^{\prime} 20^{\prime \prime} \mathrm{E}\end{array}$ & 9 October & 9 Oct & Outside, on stone wall, while alighting & 56 & 56 \\
\hline Winssen & $\begin{array}{l}51^{\circ} 53^{\prime} 11^{\prime \prime} \mathrm{N} \\
5^{\circ} 41^{\prime} 22^{\prime \prime} \mathrm{E}\end{array}$ & End of October & $3 \mathrm{Nov}$ & $\begin{array}{l}\text { Inside, unheated room and in } \\
\text { window frames }\end{array}$ & 12 & 12 \\
\hline Winterswijk & $\begin{array}{l}51^{\circ} 55^{\prime} 17^{\prime \prime} \mathrm{N} \\
6^{\circ} 43^{\prime} 8^{\prime \prime} \mathrm{E}\end{array}$ & End of November & $3 \mathrm{Dec}$ & Inside, unheated room & 11 & 11 \\
\hline
\end{tabular}

After sampling, beetles were transported at ambient temperature $\left(-2^{\circ} \mathrm{C}\right.$ to $\left.17^{\circ} \mathrm{C}\right)$ to Wageningen, the Netherlands. In Wageningen, beetles were allowed to continue overwintering in gauze bags in outdoor cages behind three wooden shutters on the righthand side of the south-facing wall of the experimental farm building of Wageningen University $\left(51^{\circ} 59^{\prime} 32^{\prime \prime} \mathrm{N}, 5^{\circ} 39^{\prime} 43^{\prime \prime} \mathrm{E}\right)$ as described earlier (Raak-van den Berg et al., 2012b). The beetles at the locations not yet sampled by early November, were still hibernating at the moment of sampling. This means that all beetles had been hibernating until they were used in the experiment. We therefore assume that the moment of sampling does not interfere with our results. Temperature was recorded every 30 min behind the middle shutter (MicrologPRO, Fourier Systems).

\section{Determination of the length of the pre-oviposition period}

To determine the occurrence of diapause, the photoperiodic response - difference in duration of pre-oviposition period at two light-regimes - was measured. Groups of ladybirds were transferred to warm conditions $\left(25 \pm 1{ }^{\circ} \mathrm{C}, 55 \pm 5 \% \mathrm{RH}\right)$ every week, and the time until oviposition of fertile eggs was recorded. Daily recordings under long-day conditions (16L : 8D) started on 8 October 2010, one day after the first migratory flight, while those under short-day conditions (12L : 12D) started on 2 November 2010, due to a technical problem with the climate room. From 21 January 2011 until 18 March 2011, transfers were made every fortnight.

After transfer, sex was determined (McCornack et al., 2007) and beetles were checked for visible infection with Hesperomyces virescens Thaxter (Laboulbeniales: Laboulbeniaceae) (Riddick \& Schaefer, 2005; De Kesel, 2011; Haelewaters et al., 2012). Non-infected beetles were paired. Both under long-day and under short-day conditions generally twenty couples were observed per transfer date (with four exceptions). After 3 December half of the couples per transfer date originated from
Tilburg and the other half from one of the other locations (Table 1). Each couple was put into a $9 \mathrm{~cm}$ Petri dish and treated as described in Raak-van den Berg et al. (2012a). Additionally, a folded strip of filter paper was added as substrate for oviposition, and aphids [Acyrthosiphon pisum Harris (Hemiptera: Aphididae)] were given daily. Aphids were reared on Vicia faba L. (Leguminosae) and provided by Koppert Biological Systems, Berkel en Rodenrijs, the Netherlands.

Petri dishes were checked daily for oviposition. To avoid cannibalism, eggs were separated from adults and checked daily for hatching. As soon as neonate larvae had crawled out of their eggshells, a batch was considered hatched. If a female did not start laying eggs within three weeks or if her eggs did not hatch, an extra male, originating from a fertile pair, was added to exclude male sterility. Observation of a female ended when the female died or when the first egg cluster hatched. If a male died before the end of the experiment, it was replaced with another male.

\section{Statistical analysis}

The time until the start of oviposition after transfer to $25^{\circ} \mathrm{C}$ was analysed using survival analysis (Raak-van den Berg et al., 2012a). Survival analysis is a method that allows for censored data - observations that are terminated before a certain critical event occurs - to be included and analysed, too. In this case, the critical event was oviposition. By using survival analysis in this study, the information that the female did not oviposit during her life is taken into account as the minimum time needed before the start of oviposition. If non-reproducing females were excluded from the analysis, this would result in an underestimation of the time until oviposition. The effect of photoperiod and dormancy length on the differences in the onset of oviposition were analysed with Kaplan Meier's Log rank test using PASW Statistics (18.0.3, 9 Sept 2010). 


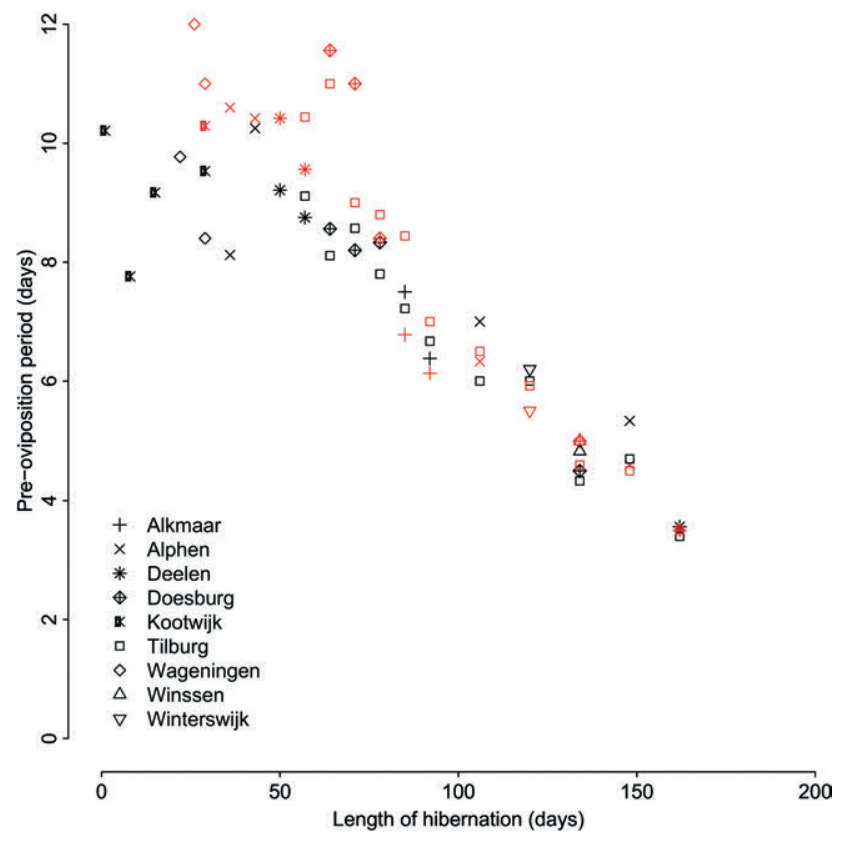

Fig. 2. Median pre-oviposition period of Harmonia axyridis females after transfer from outdoor hibernation cages to conditions representing long-day $\left(25^{\circ} \mathrm{C}, 16 \mathrm{~L}: 8 \mathrm{D}\right)$ (black) and short-day $\left(25^{\circ} \mathrm{C}, 12 \mathrm{~L}: 12 \mathrm{D}\right)(\mathrm{red})$. The $\mathrm{X}$-axis represents the length of the hibernation period (time between migratory flights and transfer). Median is given per population origin (indicated by different symbols).

\section{RESULTS}

The pre-oviposition period was determined for 722 pairs of $H$. axyridis (314 short-day, and 408 long-day). In total 18 (short-day) and 31 (long-day) females did not oviposit at all, and those observations were censored.

As shown in figure 2 all locations (including Tilburg for which an extended record is available) show a similar trend: in the beginning, longer pre-oviposition periods are measured under short-day conditions than under long-day conditions; a difference which disappears in the course of the experiment. Therefore, results were pooled over locations.

The results are clustered in four groups with different dormancy lengths: (1) group I: transfer up to 12 November, (2) group II: transfer from 19 November up to 24 December, (3) group III: transfer from 31 December up to 4 February, (4) group IV: transfer from 18 February up to 18 March.

The median pre-oviposition periods for the four groups under short-day conditions were $11,10,7$, and 4 days respectively, and under long-day conditions $9,8,7$, and 4 days respectively (Fig. 3).

The length of the pre-oviposition period under short-day conditions did not differ between groups I and II. The groups III and IV significantly differed from each other and differed from both group I and group II (for all significant pairwise comparisons: Log-rank tests with Bonferroni correction; confidence level $0.05 / 6, \chi_{1}^{2}>24.4$, $\mathrm{P}<0.001)$. The length of the pre-oviposition period under long-day conditions did not differ between groups I and II

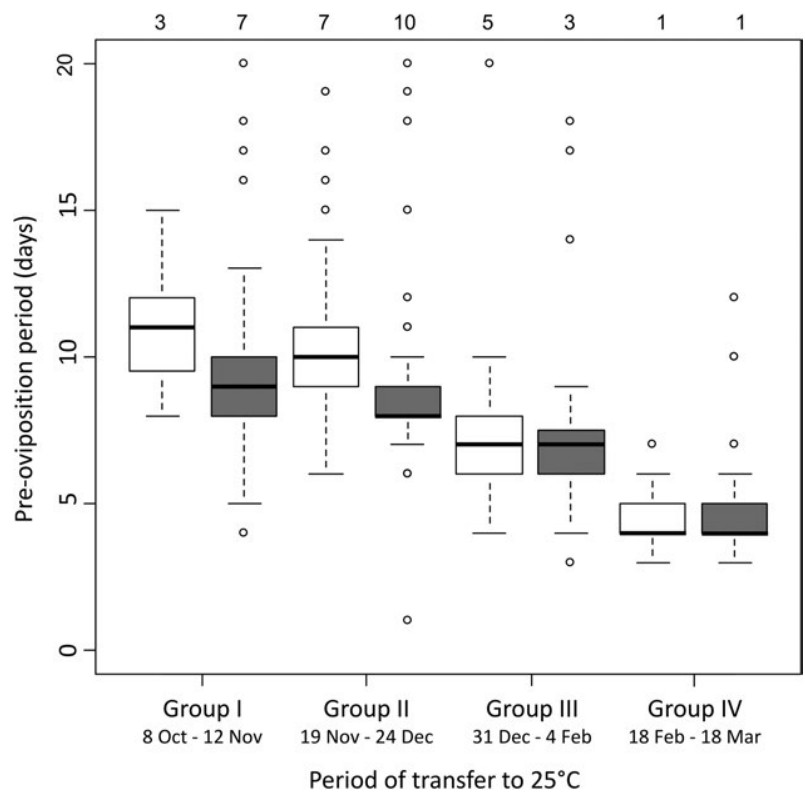

Fig. 3. Median pre-oviposition period of Harmonia axyridis females after transfer from outdoor hibernation cages to conditions representing long-day $\left(25^{\circ} \mathrm{C}, 16 \mathrm{~L}: 8 \mathrm{D}\right)$ (white box) and short-day $\left(25^{\circ} \mathrm{C}, 12 \mathrm{~L}: 12 \mathrm{D}\right)$ (grey box). The results are clustered in four groups with different dormancy lengths. The boxes represent the first to third quartile range with the thick line indicating the median. The whiskers represent a $95 \%$ confidence interval of the data. Outliers (censored and observed values) are represented by open circles; some points [16 (14 censored values) for short-day and 21 (19 censored values) for long-day] lie outside the plot range and are not shown. The number of outliers that is not shown in each group is given at the top of the graph.

either. As under short-day conditions, the groups III and IV differed from each other and from both group I and group II (for all significant pairwise comparisons: Logrank tests with Bonferroni correction; confidence level $\left.0.05 / 6, \chi_{1}^{2}>34.0, \mathrm{P}<0.001\right)$. Thus, from the end of December onwards (i.e. group III and IV), the length of the dormancy period significantly influenced the length of the pre-oviposition period: the longer the dormancy period, the shorter the pre-oviposition period (Fig. 3).

Analysis of the effect of photoperiod on the length of the pre-oviposition period stratified for dormancy group, showed that the pre-oviposition period under short-day conditions was significantly longer than under long-day conditions in dormancy groups I and II (pairwise log-rank tests per stratum: group I $\chi_{1}^{2}=10.1 ; \mathrm{P}=0.002$; group II $\left.\chi_{1}^{2}=13.1 ; \mathrm{P}<0.001\right)$. In groups III and IV short- and long-day conditions did no longer lead to significantly different pre-oviposition periods (Fig. 4).

\section{DISCUSSION}

As long as diapause has not terminated, it persists even when conditions temporarily improve. When diapause has ended, insects stay dormant in a state of post-diapause quiescence as long as unfavourable conditions are encountered, but as soon as favourable conditions arrive they will respond and resume development and reproduc- 

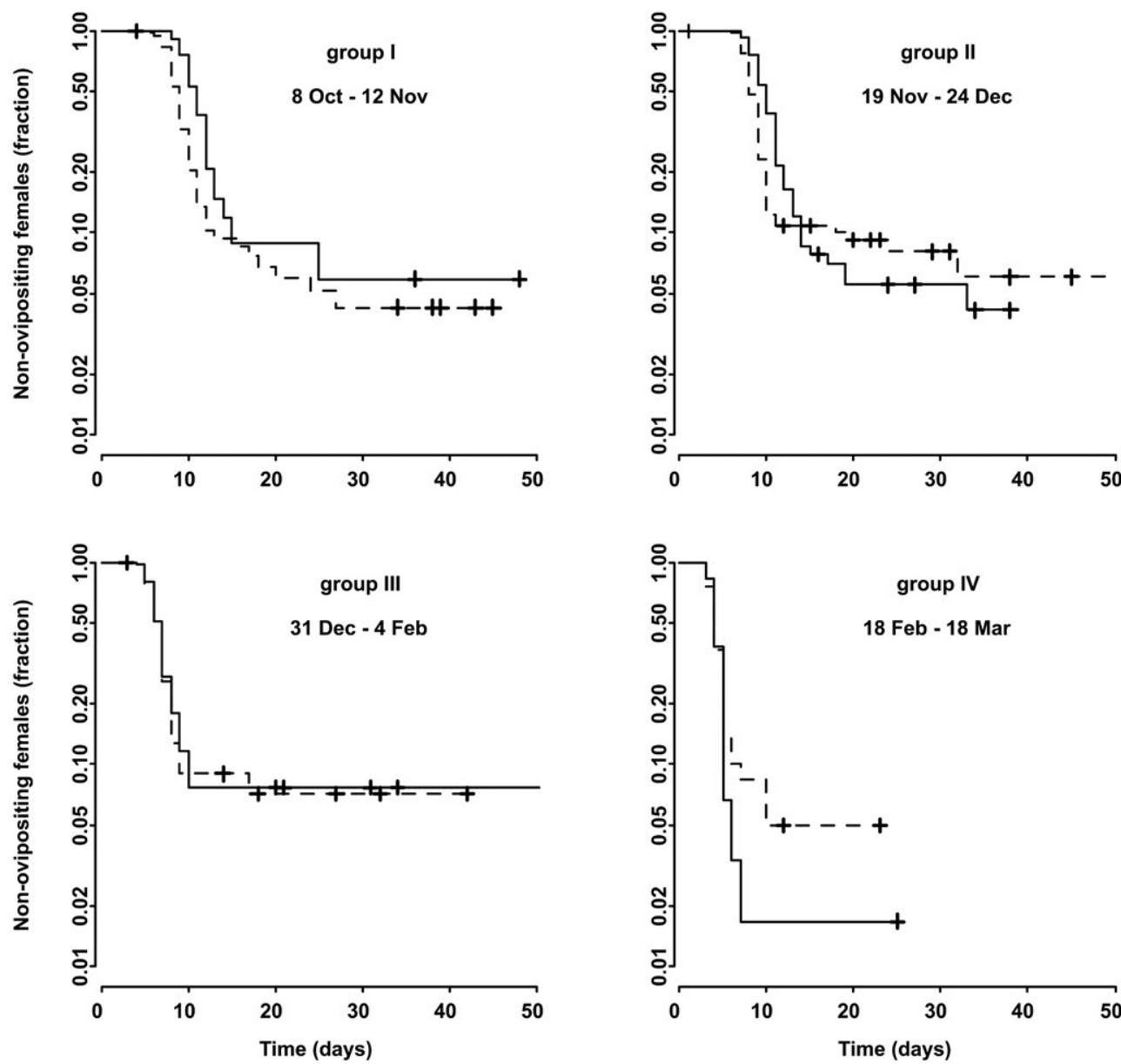

Fig. 4. Fraction of non-ovipositing females of Harmonia axyridis over time after transfer from outdoor hibernation cages to conditions representing long-day $\left(25^{\circ} \mathrm{C}, 16 \mathrm{~L}: 8 \mathrm{D}\right)$ (dashed line) and short-day $\left(25^{\circ} \mathrm{C}, 12 \mathrm{~L}: 12 \mathrm{D}\right)$ (solid line). Observation of a female ended when the female died or when the first egg cluster hatched. The data are grouped on the basis of the length of the hibernation period of the beetles (see text). Censored values (females dying before oviposition) are marked with + .

tion (Tauber et al., 1986). The observed photoperiodic response (the difference in pre-oviposition period under short and long photoperiods) until mid-December indicates that $H$. axyridis starts overwintering in a state of diapause. By the end of December the pre-oviposition periods under both photoperiods are equally long, showing that diapause has ended, as it is not maintained by the short photoperiod anymore. We may, thus, conclude that $H$. axyridis exhibits a short period of diapause.

We suggested earlier that $H$. axyridis shifts from diapause to a post-diapause quiescent state in December (Raak-van den Berg et al., 2012a). The current study confirms this, as until mid-December significantly longer pre-oviposition periods occur under short-day than under long-day conditions. Our hypothesis that $H$. axyridis starts overwintering with a period of diapause is further supported by the fact that $H$. axyridis also shows behaviour (migration and overwintering site selection before winter arrives) and physiological adaptations (regressed ovaries and a reduced fat body) that are typical of diapause (e.g. Obata, 1986; Nalepa et al., 1996; Iperti \& Bèrtand, 2001).

The native ladybirds Coccinella septempunctata L. (Coleoptera: Coccinellidae) and Adalia bipunctata L.
(Coleoptera: Coccinellidae) hibernate in diapause as well. In northern and western Europe C. septempunctata is univoltine and diapause occurs in every generation, while A. bipunctata is multivoltine, like $H$. axyridis. Coccinella septempunctata enters diapause in August/September and A. bipunctata in October. In December both species still show a response to photoperiod (Hodek et al., 1977; Obrycki et al., 1983; Brakefield, 1985; Honek, 1989; Hodek \& Honek, 1996; Brown et al., 2008; Hodek, 2012a). In March, the photoperiodic response of $A$. bipunctata is almost absent (Obrycki et al., 1983) and the beetles start emerging (Hemptinne \& Naisse, 1988). The diapause development in C. septempunctata is completed in mid-winter, but emergence from hibernation sites occurs only from March to May (Shands et al., 1972; Honek, 1989; Nedved, 1993). The total length of the diapause period of $H$. axyridis is shorter than that of $A$. bipunctata and much shorter than that of $C$. septempunctata.

Beetles of the species C. septempunctata and A. bipunctata show a stronger photoperiodic response than $H$. axyridis adults, indicating that diapause of the former two species is stronger. For beetles sampled in October the difference in pre-oviposition periods under long and short 
photoperiod is about fifty days for C. septempunctata and more than sixty days for $A$. bipunctata, while more than half of the females of both species do not start oviposition at all under short photoperiods (Hodek \& Ruzicka, 1979; Obrycki et al., 1983). Instead, for the October sample in this study with $H$. axyridis (group I: October-half November) the difference between the light regimes in median pre-oviposition period was two days, and no more than $5 \%$ of the females did not oviposit at all under short day conditions. This shows that diapause of $H$. axyridis is weaker than that of both native species.

In this study, the median pre-oviposition periods for the long-day groups II, III, and IV [median (ci): 8 (7.7-8.3), 7 (6.6-7.4), and 4 (3.7-4.3) days], showed a similar trend as those found in the previous study [median (ci): 10 (9.4-10.6), 8 (7.6-8.3), and 5 (4.7-5.3) days respectively] (Raak-van den Berg et al., 2012a), but they were shorter. In the winter of 1992-1993 Iperti \& Bèrtand (2001) found median pre-oviposition periods in $H$. axyridis that were twice as long as those in this study. This was shortly after the first field experiments were conducted in southeastern France in 1990 (Brown et al., 2008). We therefore expect that the beetles had not yet adapted to the local conditions. Furthermore, environmental conditions (longterm averages) are comparable for south-eastern France and the Netherlands during the period of migratory flights and the first period of diapause (Raak-van den Berg et al., 2012a). Although we cannot exclude the potential role of the use of an artificial diet versus natural prey in the difference between these and our present results (Hodek \& Honek, 1996), this observation suggests that pre-oviposition period has shortened over the last two decades.

The apparent shortening of pre-oviposition period over the last decade may indicate a rapid change in diapausing behaviour of the $H$. axyridis population in Europe. This is supported by the fact that Berkvens et al. (2010) were not able to induce diapause anymore in a field-collected population in 2008, while they still managed to do so in 2005 with the fourth generation of a field-collected population (Berkvens et al., 2008).

When a population enters a new area, new and interesting changes in diapause behaviour can occur while the species adapts to the new circumstances. The Colorado potato beetle, Leptinotarsa decemlineata (Say) (Coleoptera: Chrysomelidae), for example, has shifted from diapause induced by low food quality in its native range (southern Mexico), to diapause induced by short photoperiod in the new area (northern USA and Europe), with the critical photoperiod depending on the latitude. Its behaviour has changed, too. In the new area it buries itself in the ground during diapause to avoid freezing temperatures, while it stays above ground in its native area (De Wilde \& Hsiao, 1981; Hsiao, 1985).

Compared with the native species $C$. septempunctata and $A$. bipunctata, exotic $H$. axyridis has a short and remarkably weak diapause, which apparently does not reduce overwintering survival (Raak-van den Berg et al., $2012 b$ ). On the other hand, this short diapause is not directly advantageous for $H$. axyridis either, as the moment that adults become active in spring is similar for all three species (Raak-van den Berg et al., 2012a), and thus population build-up will generally start at approximately the same time. However, our data seem to suggest that, since diapause in $H$. axyridis lasts only a short period of time and appears to be weaker than that of native species, $H$. axyridis might be able to respond more opportunistically to variation in winter-climatic regimes. We hypothesise that this flexibility may give $H$. axyridis an advantage over native competitors, especially under present trends of climate-change, with earlier onset of spring conditions in western Europe (Hodkinson, 2011). However, considerable testing is needed to confirm our hypothesis, which may be further explored by simultaneously monitoring hibernation, overwintering survival, and spring activity of $H$. axyridis and native species at the same location(s). Thus, it probably is not the mode of hibernation but the plasticity and adaptability of its diapausing behaviour that contributes to the invasive success of $H$. axyridis.

ACKNOWLEDGEMENTS. We would like to thank the following persons and organisations for various contributions: S.W. Benedictus-van den Berg, C.A.J.M. van Boxel, Mr \& Mrs Van den Berg-van Boxel, I. Folkertsma, A. Hakman, Mr \& Mrs Huijsman, Mr \& Mrs Van der Kamp, J. van Kemenade, K. Kots, B. Lodeweges, A.J.M. Loomans, G. Mekking, M.J. Raak, D. Rozeboom, A. Siepel, J. Spitzen, J.M. Stam, T. Timmer, W. van Tol, E. Voorhout, and P. van Wielink. We thank two anonymous reviewers for constructive comments on an earlier version of the manuscript.

\section{REFERENCES}

Alyokhin A. \& Sewell G. 2004: Changes in a lady beetle community following the establishment of three alien species. Biol. Invasions 6: 463-471.

Berkvens N., Bonte J., Berkvens D., Tirry L. \& De Clerce P. 2008: Influence of diet and photoperiod on development and reproduction of European populations of Harmonia axyridis (Pallas) (Coleoptera: Coccinellidae). - BioControl 53: 211-221.

Berkvens N., Bale J.S., Berkvens D., Tirry L. \& De Clerce P. 2010: Cold tolerance of the Harlequin ladybird in Europe. J. Insect Physiol. 56: 438-444.

BRAKEFIELD P.M. 1985: Differential winter mortality and seasonal selection in the polymorphic ladybird Adalia bipunctata in the Netherlands. - Biol. J. Linn. Soc. 24: 189-206.

Brakefield P.M. \& de Jong P.W. 2011: A steep cline in ladybird melanism has decayed over 25 years: a genetic response to climate change? - Heredity 107: 574-578.

Brown P.M.J., Adriaens T., Bathon H., Cuppen J., Goldarazena A., Hagg T., Kenis M., Klausnitzer B.E.M., Kovar I., Loomans A.J.M., Majerus M.E.N., Nedved O., Pedersen J., Rabitsch W., Roy H.E., Ternols V., Zakharov I.A. \& Roy D.B. 2008: Harmonia axyridis in Europe: spread and distribution of a non-native coccinellid. - BioControl 53: 5-21.

Brown P.M.J., Thomas C.E., Lombaert E., Jefrries D.L., Estoup A. \& Lawson Handley L.-J. 2011: The global spread of Harmonia axyridis (Coleoptera: Coccinellidae): distribution, dispersal and routes of invasion. - BioControl 56: 623-641.

De Clerce P. \& Bale J.S. 2011: Risks of invertebrate biological control agents - Harmonia axyridis as a case study. In Ehlers 
R.-U. (ed.) Regulation of Biological Control Agents. Springer, Dordrecht, pp. 243-255.

De Kesel A. 2011: Hesperomyces (Laboulbeniales) and coccinellid hosts. - Sterbeeckia 30: 32-37.

De Wilde J. \& Hsiao T. 1981: Geographic diversity of the Colorado Potato Beetle and its infestation in Eurasia. In Lashomb J.H. \& Casagrande R. (eds): Advances in Potato Pest Management. Hutchinson Ross, Stroudsburg, pp. 47-68.

DenLINGer D.L. 2002: Regulation of diapause. - Annu. Rev. Entomol. 47: 93-122.

Haelewaters D., Van Wielink P., Van Zuijlen J.W., Verbeken A. \& De Kesel A. 2012: New records of Laboulbeniales (Fungi, Ascomycota) for the Netherlands. - Entomol. Ber. 72: $26-33$.

Hemptinne J.-L. \& NAisse J. 1988: Life cycle strategy of Adalia bipunctata (L.) (Col., Coccinellidae) in a temperate country. In Niemczyk E. \& Dixon A.F.G. (eds): Ecology and Effectiveness of Aphidophaga: Proceedings of an International Symposium, Held at Teresin, Poland, August 31 - September 5, 1987. SPB Academic Publishing, The Hague, pp. 71-77.

Hodek I. 2012a: Adult diapause in Coleoptera. - Psyche 2012: $1-10$.

Hodek I. 2012b: Diapause/dormancy. In Hodek I., van Emden H.F. \& Honek A. (eds): Ecology and Behaviour of the Ladybird Beetles (Coccinellidae). Blackwell, Chichester, pp. 275-342.

Hodek I. \& Hodkova M. 1988: Multiple role of temperature during insect diapause: a review. - Entomol. Exp. Appl. 49: 153-165.

Hodek I. \& HoneK A. 1996: Ecology of Coccinellidae. Kluwer, Dordrecht, $464 \mathrm{pp}$.

Hodek I. \& RuZICKA Z. 1979: Photoperiodic response in relation to diapause in Coccinella septempunctata (Coleoptera) Acta Entomol. Bohemoslov. 76: 209-218.

Hodek I., IPeRTi G. \& Rolley F. 1977: Activation of hibernating Coccinella septempunctata (Coleoptera) and Perilitus coccinellae (Hymenoptera) and the photoperiodic response after diapause. - Entomol. Exp. Appl. 21: 275-286.

Hodkinson T.R. 2011: Climate Change, Ecology and Systematics. Cambridge University Press, Cambridge, 524 pp.

Honek A. 1989: Overwintering and annual changes of abundance of Coccinella septempunctata in Czechoslovakia (Coleoptera, Coccinellidae). — Acta Entomol. Bohemoslov. 86: 179-192.

Hsiao T.H. 1985: Ecophysiological and genetic aspects of geographic variations of the Colorado potato beetle. In Ferro D.N. \& Voss R.H. (eds): Proceedings of the Symposium on the Colorado Potato Beetle, 17th International Congress of Entomology. University of Massachusetts, Amherst, pp. $63-77$.

IPERTI G. \& BÈRTAND E. 2001: Hibernation of Harmonia axyridis (Coleoptera: Coccinellidae) in South-Eastern France. - Acta Soc. Zool. Bohem. 65: 207-210.

KNMI 2011: Maand- en jaarwaarden van de temperatuur, neerslag en luchtdruk De Bilt. In: Koninklijk Nederlands Meteorologisch Instituut. http://www.knmi.nl/klimatologie/ maandgegevens/index.html Accessed: 25 November 2010.

Koch R.L. \& Galvan T.L. 2008: Bad side of a good beetle: the North American experience with Harmonia axyridis. - BioControl 53: 23-35.

McCornack B.P., Koch R.L. \& Ragsdale D.W. 2007: A simple method for in-field sex determination of the multicolored Asian lady beetle Harmonia axyridis. - J. Insect Sci. 7: 12.

Michaud J.P. 2002: Invasion of the Florida citrus ecosystem by Harmonia axyridis (Coleoptera: Coccinellidae) and asym- metric competition with a native species, Cycloneda sanguinea. - Environ. Entomol. 31: 827-835.

Nalepa C.-A., Kidd K.-A. \& Ahlstrom K.-R. 1996: Biology of Harmonia axyridis (Coleoptera: Coccinellidae) in winter aggregations. - Ann. Entomol. Soc. Am. 89: 681-685.

Nalepa C.A., Kennedy G.G. \& Brownie C. 2005: Role of visual contrast in the alighting behavior of Harmonia axyridis (Coleoptera: Coccinellidae) at overwintering sites. - Environ. Entomol. 34: 425-431.

Nedved O. 1993: Comparison of cold hardiness in two ladybird beetles (Coleoptera: Coccinellidae) with contrasting hibernation behaviour. - Eur. J. Entomol. 90: 465-470.

Овата S. 1986: Determination of hibernation site in the ladybird beetle, Harmonia axyridis Pallas (Coleoptera, Coccinellidae). - Kontyu 54: 218-223.

Obrycki J.J., Tauber M.J., Tauber C.A. \& Gollands B. 1983: Environmental control of the seasonal life cycle of Adalia bipunctata (Coleoptera: Coccinellidae). - Environ. Entomol. 12: 416-421.

Ongagna P. \& IPERTI G. 1994: Influence of temperature and photoperiod in Harmonia axyridis Pall. (Col., Coccinellidae): rapidly obtaining fecund adults or in dormancy. - J. Appl. Entomol. 117: 314-317.

Raak-van den Berg C.L., Hemerik L., Jong P.W.d. \& Lenteren J.C.v. 2012a: Mode of overwintering of invasive Harmonia axyridis in the Netherlands. - BioControl 57: 71-84.

RaAk-van den Berg C.L., Stam J.M., Jong P.W.D., Hemerik L. \& LENTEREN J.C.v. 2012b: Winter survival of Harmonia axyridis in The Netherlands. - Biol. Control 60: 68-76.

ReZnIK S.Y. \& VAGHINA N.P. 2011: Photoperiodic control of development and reproduction in Harmonia axyridis (Coleoptera: Coccinellidae). - Eur. J. Entomol. 108: 385-390.

Riddick E.-W. \& Schaefer P.-W. 2005: Occurrence, density, and distribution of parasitic fungus Hesperomyces virescens (Laboulbeniales: Laboulbeniaceae) on multicolored Asian lady beetle (Coleoptera: Coccinellidae). - Ann. Entomol. Soc. Am. 98: 615-624.

Roy H.E., Adriaens T., Isaac N.J.B., Kenis M., Onkelinx T., San Martin G., Brown P.M.J., Hautier L., Poland R., Roy D.B., Comont R., Eschen R., Frost R., Zindel R., Van Vlaenderen J., Nedved O., Ravn H.P., Gregoire J.C., de BISEAU J.C. \& MAES D. 2012: Invasive alien predator causes rapid declines of native European ladybirds. - Divers. Distrib. 18: 717-725.

Sakurai H., Kawai T. \& Takeda S. 1992: Physiological changes related to diapause of the lady beetle, Harmonia axyridis (Coleoptera: Coccinellidae). - Appl. Entomol. Zool. 27: 479-487.

Shands W.A., Simpson G.W. \& Storch R.H. 1972: Insect predators for controlling aphids on potatoes. 9. Winter survival of Coccinella species in field cages over grassland in northeastern Maine. - J. Econ. Entomol. 65: 1392-1396.

TANAGISHI K. 1976: Hibernation of the ladybeetle Harmonia axyridis. - Insectarium 13: 294-298.

Tauber M.J., Tauber C.A. \& Masaki S. 1986: Seasonal Adaptations of Insects. Oxford University Press, New York, 411 pp.

VAN LENTEREN J.C. 2012: The state of commercial augmentative biological control: plenty of natural enemies, but a frustrating lack of uptake. - BioControl 57: 1-20.

VAn Lenteren J.C., LoOMAns A.J.M., BabendReier D. \& Bigler F. 2008: Harmonia axyridis: an environmental risk assessment for Northwest Europe. - BioControl 53: 37-54.

Received January 14, 2013; revised and accepted May 13, 2013 